\title{
Experimental Study on Interception Failure of Lightning Protection System of Wind Turbine Blade
}

\author{
Waqas Arif ${ }^{1}$, Qingmin $\mathrm{Li}^{1}$, Zixin Guo ${ }^{1}$, Muhammad Ali Aizaz ${ }^{2}$, Yufei $\mathrm{Ma}^{1}$, Wah Hoon Siew ${ }^{3}$ \\ ${ }^{1}$ School of Electrical and Electronics Engineering, North China Electric Power University, Beijing 102206, China \\ ${ }^{2}$ Department of Electrical Engineering, University of South Asia, Lahore 55150, Pakistan \\ ${ }^{3}$ Department of Electronic and Electrical Engineering, The University of Strathclyde, Glasgow G1 1XQ, United Kingdom \\ waqasarif@qq.com, lqmeee@ncepu.edu.cn, guoxicin@126.com, ali.aizaz@usa.edu.pk, 15652912154@163.com, \\ wh.siew@strath.ac.uk
}

\begin{abstract}
Wind turbine (WT) blades are equipped with lightning protection system (LPS) consisting of receptors and down conductor in order to intercept lightning strikes. However, severe damages caused by lightning strikes still happen frequently, which costs huge losses. In this paper, experiments were conducted to study the lightning interception failure of WT blade LPS, and the results can be useful to improve the optimal design of LPS. Experiments using $5 \mathrm{~m}$ blade specimen with tip receptor from $1.5 \mathrm{MW}$ wind turbine under $3 \mathrm{~m}$ air gap are conducted to investigate the lightning interception failure of LPS in different orientations and lateral distances (LDs). Factors such as the polarity of lightning strikes, the blade orientation of wind turbine and lateral distance between wind turbine and lightning downward leader were investigated. The lateral distance between downward leader (DL) and wind turbine blade is a key factor which influences the interception efficiency. Three patterns of receptor interception failure are discovered. The protection area shows asymmetry under different lateral distance. Multi-upward leaders (UL) from WT blade have been observed in the experiment.
\end{abstract}

Index Terms - Lightning protection, Wind turbine blade, receptor, Lightning attachment, Multi-upward leaders

\section{INTRODUCTION}

$\mathrm{W}$ ind turbine is a nonstandard construction with rotating elements which is extremely exposed to the electrical environment. The most frequent damages happens to the blades, which are the most expensive single components of the turbine [1], [2] More than $88 \%$ of lightning attachments occur within the outermost $1 \mathrm{~m}$ of the blade tip, where the thickness of the surface skin is around 2-10 $\mathrm{mm}$, but increased risk of inboard puncture for lightning strike of smaller current than $20 \mathrm{kA}$ is also noticed [3]. Current LPS for WT blades are designed to withstand about $98 \%$ of lightning strikes, but there is still a risk of local damage, particularly at the attachment point [4], [5]. Lightning damage occurs to blades, generator, controller, control cables, etc. Among those, the blades are the most vulnerable components, which show the highest frequency (approximately 75\%), highest repair cost, and longest downtime (approximately ten days per lightning incident) [6]. In addition, the increasing size of wind turbines in the recent years also poses significant challenges for the development of lightning protection system since the number of lightning strikes grows with the increase of structure height [7].

Field observation shows that the numbers of lightning strikes to wind turbine blade in orientation of $90^{\circ}, 60^{\circ}$ and $30^{\circ}$ share similar proportion [8]. However, the behavior of receptor is different under different blade orientations.

Some researchers use long air gap experiment to simulate the behavior of lightning strikes hit on blades with different kinds of receptors [9]-[12]. Simulation work has been done to discover the mechanism of upward inception of wind turbine [13], and to analyze the protection area of receptors [14]. Most manufacturers have decided the strategy of designing blade's LPS according to the research and operation experience. However, the wind turbine blades are still hit by lightning strikes. The reason, why LPS of wind turbine blade fails to intercept lightning downward leader remains a question.

The process of interception failure needs to be reproduced by experiments first, and then the model can be modified to simulate the fact more accurately.

In this paper, experiments are conducted to investigate how the receptor behaves to lightning strikes and how the LPS fails to intercept it. Different situations, including positive and negative polarity impulse, different blade orientations and different lateral distances, are taken into consideration. The asymmetrical influence of lateral distance is analyzed. The patterns of receptor interception failure under positive discharge are summarized.

\section{EXPERIMENTAL WORK}

\section{A. Description of wind turbine blade specimen}

In consideration of both operating feasibility and experimental comparability, 5m Glass fiber reinforced polymer (GFRP) wind turbine blade tip is used to conduct the experiments, WT blade specimen cut from SINOMA45.2B which was designed for $1.5 \mathrm{MW}$ Wind turbine and the length was $45.2 \mathrm{~m}$. The blade specimen is equipped with lightning protection system including an aluminum-made tip receptor and $70 \mathrm{~mm}^{2}$ copper stranded conductor inside blade chamber connected to the ground as shown in Figure 1. 


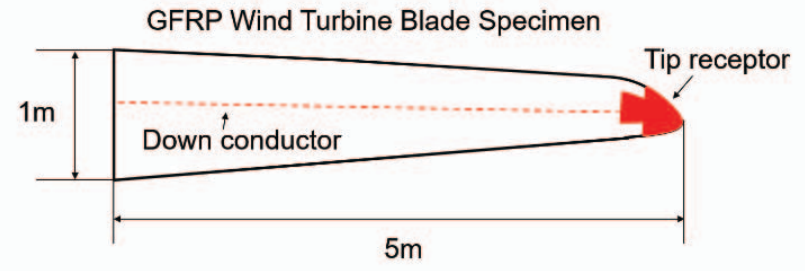

Fig. 1. The 5m GFRP wind turbine blade specimen with an aluminum tip receptor and $70 \mathrm{~mm}^{2}$ copper down conductor inside blade chamber.

\section{B. Arrangement of the experimental setup}

Experiment tests were conducted outdoors at Shahe testing yard of North China Electric Power Research Institute (NCEPRI) in China, and more than 200 strikes were applied. In order to produce the background electric field similar to real lightning, the voltage waveform is $250 / 2500 \mu \mathrm{s}$ (positive \& negative) standard switching impulse were obtained using a $5.4 \mathrm{MV}, 405 \mathrm{~kJ}, 28$ stages impulse generator. The discharge voltage was measured using a voltage divider. A rod electrode was employed as the downward leader and the vertical height between the tip of wind turbine blade specimen and the bottom of rod electrode is $3 \mathrm{~m}$. The blade specimen is elevated above the ground on a $1 \mathrm{~m}$ non-conductive support. A digital camera is used to capture the discharge behavior by longexposure, and a high-speed camera Phantom V1210 is used to capture the discharge process by long-exposure. The frame rate is $240601 \mathrm{fps}(4.156 \mu \mathrm{s} /$ frame $)$, and the resolution is $128 \times 128 \mathrm{pixel}$. The breakdown voltages were measured using an oscilloscope. The breakdown probability is approximately $100 \%$ for the applied voltage. The practical test platform configuration is displayed in Figure 2.

There are 3 kinds of typical orientations: $30^{\circ}, 60^{\circ}$ and $90^{\circ}$ with horizontal. In this paper, $90^{\circ}$ and $30^{\circ}$ are used for the experiments. The lateral distance (LD) between rod electrode and the tip of blade specimen is adjustable in order to simulate lightning strikes coming from different directions. The ratio between the horizontal distance from downward leader tip to the bottom of blade and the length of blade is proposed to classify different lateral distances (LD) from different directions:

$$
R=\frac{L_{\text {tip-bottom }}}{L_{\text {blade }}}
$$

Where $L_{\text {tip-bottom }}$ is the horizontal distance between downward leader and the foot point of vertical line from the blade tip to the blade bottom, $L_{\text {blade }}$ is the horizontal distance from the blade tip to the blade bottom (foot point), as shown in Figure 3.

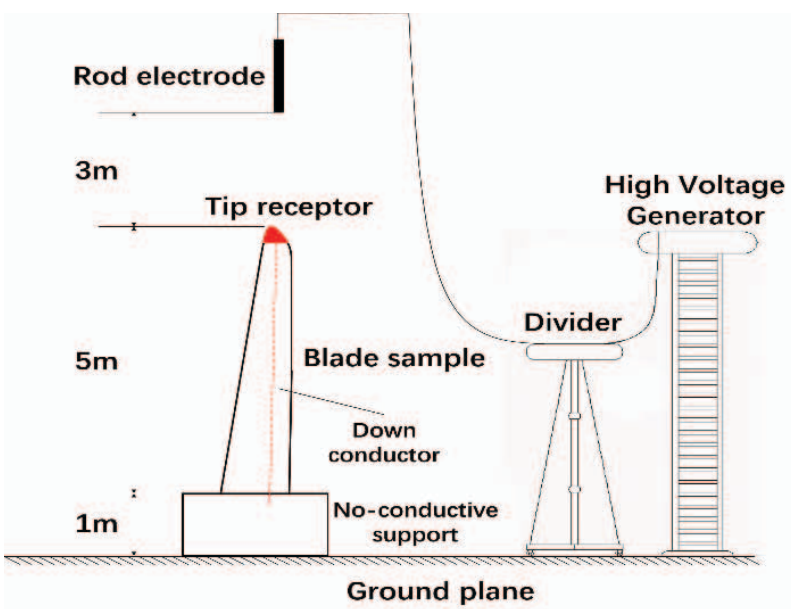

(a)

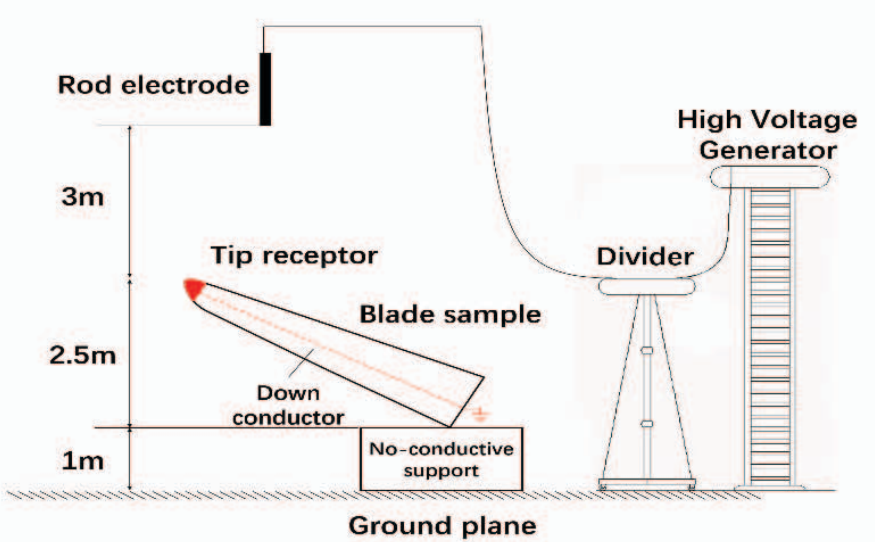

(b)

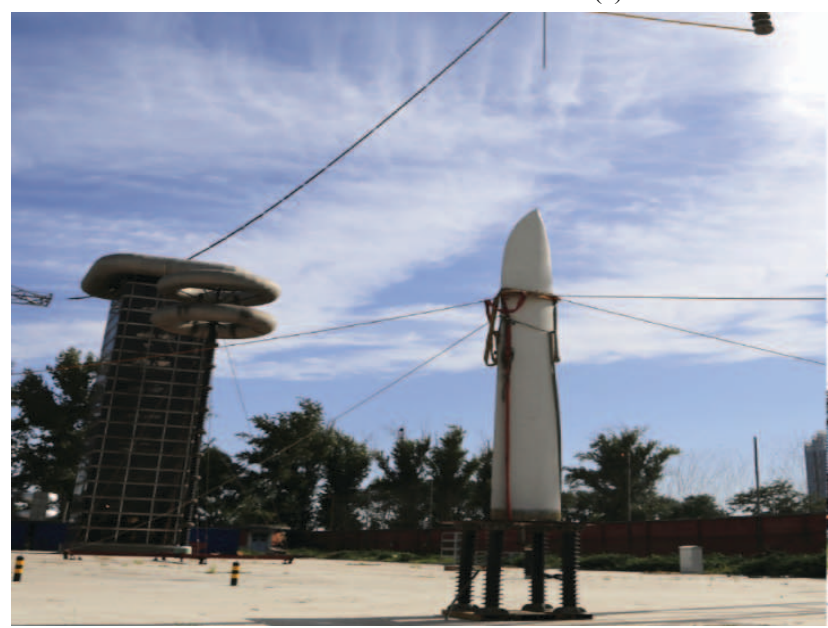

(c)

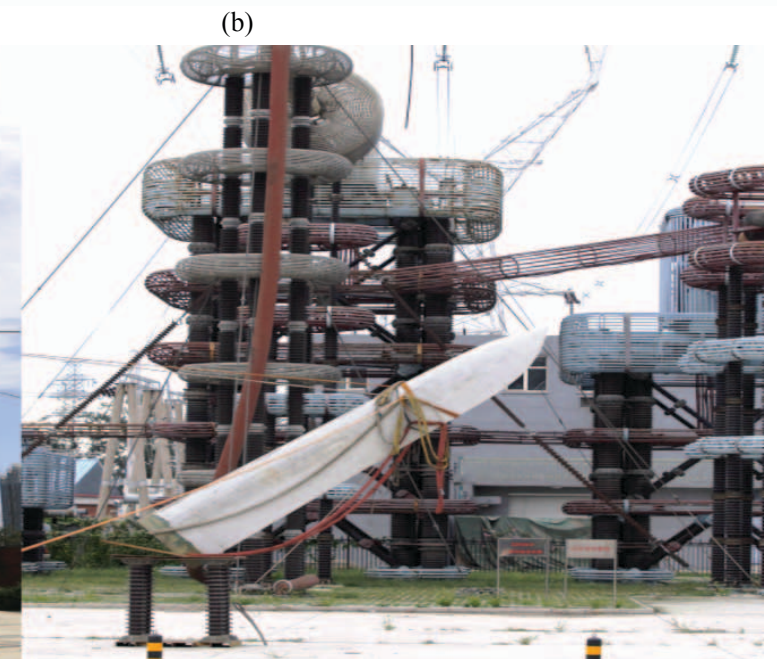

Fig. 2. (a) Test platform configuration for blade orientation $90^{\circ}$ with horizontal. (b) Test platform configuration for blade orientation $30^{\circ}$ with horizontal. (c) Experiment setup 
Lateral distance can be divided into 3 groups:

- $\quad \mathrm{R}>1$, DL comes from direction far from wind turbine blade. LD is $-1.5 \mathrm{~m}$.

- $\mathrm{R}=1$, DL comes from above the tip of wind turbine blade. LD is $0 \mathrm{~m}$.

- $\quad \mathrm{R}<1$, DL comes from direction close to wind turbine blade. LD are $0.75 \mathrm{~m}, 1.5 \mathrm{~m}$ and $2.25 \mathrm{~m}$.

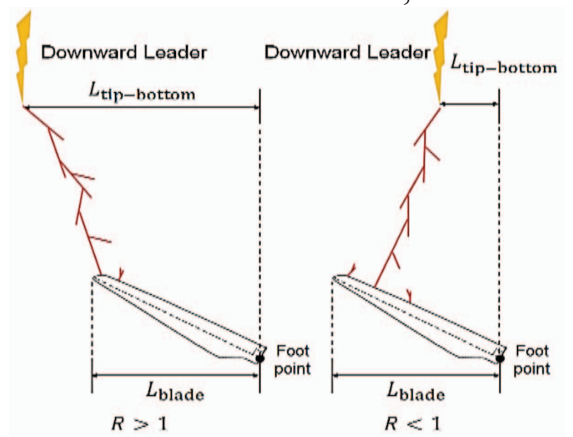

Fig. 3. The ratio between the horizontal distance from downward leader tip to the bottom of blade and the length of blade is proposed to classify different lateral distances. $\mathrm{R}>1$ : $\mathrm{LD}=-1.5 \mathrm{~m} ; \mathrm{R}=1$ : $\mathrm{LD}=0 \mathrm{~m} ; \mathrm{R}<1$ :

$$
\mathrm{LD}=0.75 \mathrm{~m}, 1.5 \mathrm{~m} \text { and } 2.25 \mathrm{~m} \text {. }
$$

5 different lateral distances $(\mathrm{LD}=-1.5,0,0.75,1.5,2.25)$ were used to simulate lightning strike from different directions as shown in figure 4.

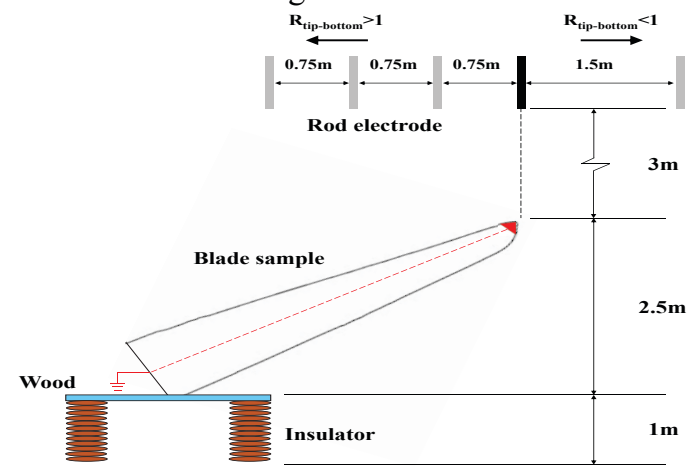

Fig. 4. Different lateral distance

The attachment points can be classified into 4 types as showed in Table I and Figure 5.

TABLE I

FOUR TYPES OF STRIKING ATTACHMENT POINT

\begin{tabular}{ccc}
\hline \hline Type I & Tip receptor & Receptor tip \\
\cline { 1 - 1 } Type II & & Receptor side \\
\hline Type III & Blade body & $\begin{array}{c}\text { Blade surface close to tip } \\
\text { receptor }\end{array}$ \\
Type IV & & $\begin{array}{c}\text { Blade surface far from tip } \\
\text { receptor }\end{array}$ \\
\hline \hline
\end{tabular}

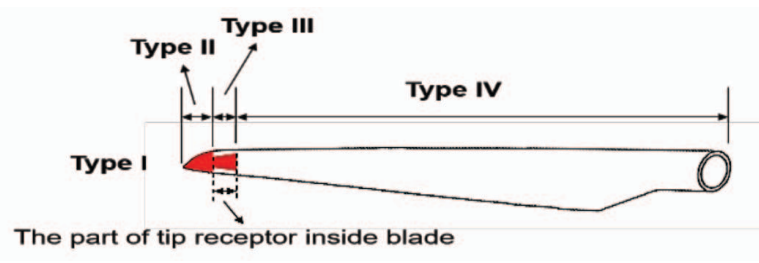

Fig. 5. Four types of striking attachment point.

\section{RESULT}

Experiments were conducted with both positive and negative standard switching impulses under different orientations and lateral distances. The results show very strong polarity effect. In Section A, the performance of LPS when the orientation of WT blade is $90^{\circ}$ with horizontal. In Section B, the performance of LPS when the orientation of WT blade is $30^{\circ}$ with horizontal. In Section $\mathrm{C}$, three patterns of receptor interception failure were observed during experiments with positive impulse under orientation of $30^{\circ}$ with horizontal $(\mathrm{LD}=2.25 \mathrm{~m})$.

\section{A. The performance of LPS when the orientation of WT} blade is $90^{\circ}$ with horizontal

Both positive and negative standard switching impulse were conducted (20 times for each polarity) for $90^{\circ}$ orientation of WT blade with horizontal. In Table II, all the discharges hit on the tip receptor and upward leaders were observed. The paths of positive discharges are scattered and converging at the tip receptor, as shown in Figure 6(a), and negative discharges just develop straightly downward to the tip receptor, as shown in Figure 6(b). All discharges hits on the tip of receptor except one positive discharge which hits on the boundary of tip receptor and blade body, which may cause damage to wind turbine blade. For tip receptor, intercepting negative discharges is much easier than the positive ones. The position of connection points is at about $40 \%$ (from the blade tip) of the gap, as shown in Figure 6(c) and (d).

Under $90^{\circ}$ with horizontal, if leader propagates downward from any direction, the tip receptor will incept upward leader and then intercept the downward leader. Positive discharges were much more scattering and diverging than negative ones, which is more rigorous for WT blade LPS, so that only standard positive switching impulses were applied to the $30^{\circ}$ orientation under different LD.

TABLE II

DISCHARGE MANNER FOR ORIENTATION OF $90^{\circ}$ WITH HORIZONTAL

\begin{tabular}{|c|c|c|c|c|c|c|c|c|}
\hline \multirow{4}{*}{ Polarity } & \multirow{4}{*}{$\begin{array}{c}\text { Average } \\
\text { breakdown voltage } \\
(\mathrm{kV})\end{array}$} & \multicolumn{6}{|c|}{ Striking attachment point } & \multirow{3}{*}{ Total } \\
\hline & & \multicolumn{4}{|c|}{ Tip receptor } & \multirow{2}{*}{\multicolumn{2}{|c|}{ Blade surface }} & \\
\hline & & \multicolumn{2}{|c|}{ Tip } & \multicolumn{2}{|c|}{ Side } & & & \\
\hline & & Times & $\%$ & Times & $\%$ & Times & $\%$ & Times \\
\hline Negative & 1700.65 & 20 & $100 \%$ & 0 & $0 \%$ & 0 & $0 \%$ & 20 \\
\hline Positive & 1164.70 & 19 & $95 \%$ & 1 & $5 \%$ & 0 & $0 \%$ & 20 \\
\hline
\end{tabular}




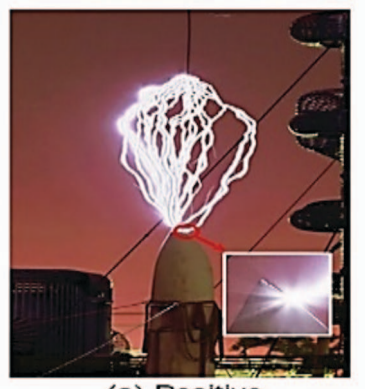

(a) Positive

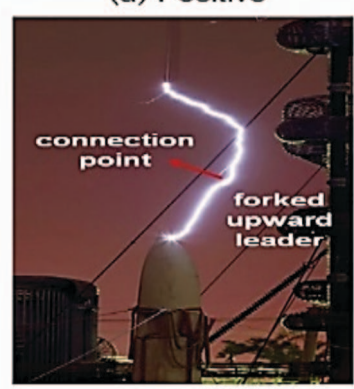

(c) Connection point (positive)

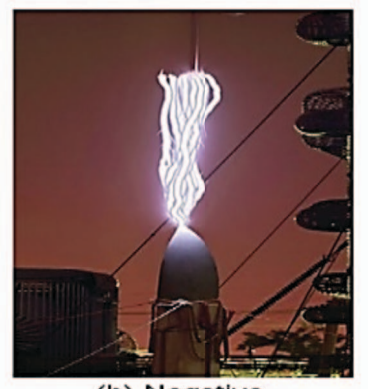

(b) Negative

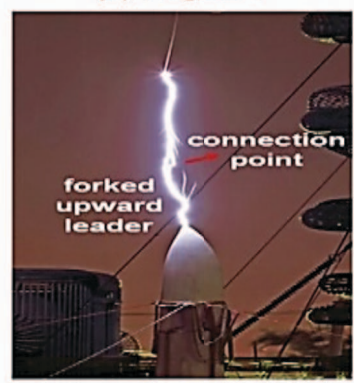

(d) Connoction point (negative)
Fig. 6. (a) The paths of total 20 times positive discharges. (b) The paths of total 20 times negative discharges. (c) The position of positive discharge connection points is at about $40 \%$ of the gap. (d) The position of negative discharge connection points is at about $40 \%$ of the gap.

\section{$B$. The performance of LPS when the orientation of WT} blade is $30^{\circ}$ with horizontal

20 times standard positive switching impulse were applied for each lateral distance as shown Figure 7 and results are tabulated in Table III.

The interception efficiency of tip receptor reaches maximum (approximately 95\%) when lateral distance was $0 \mathrm{~m}$. With the increasing of lateral distance both $\mathrm{R}>1$ and $\mathrm{R}<1$ condition, the efficiency decreases with different speed and shows obvious asymmetry. For $\mathrm{R}<1$ condition, the interception efficiency decreases much faster than $\mathrm{R}>1$, which means the protection area of tip receptor depends on lateral distance and has some kind of directionality. The attachment manner changes with different lateral distances, as shown in Figure 8.
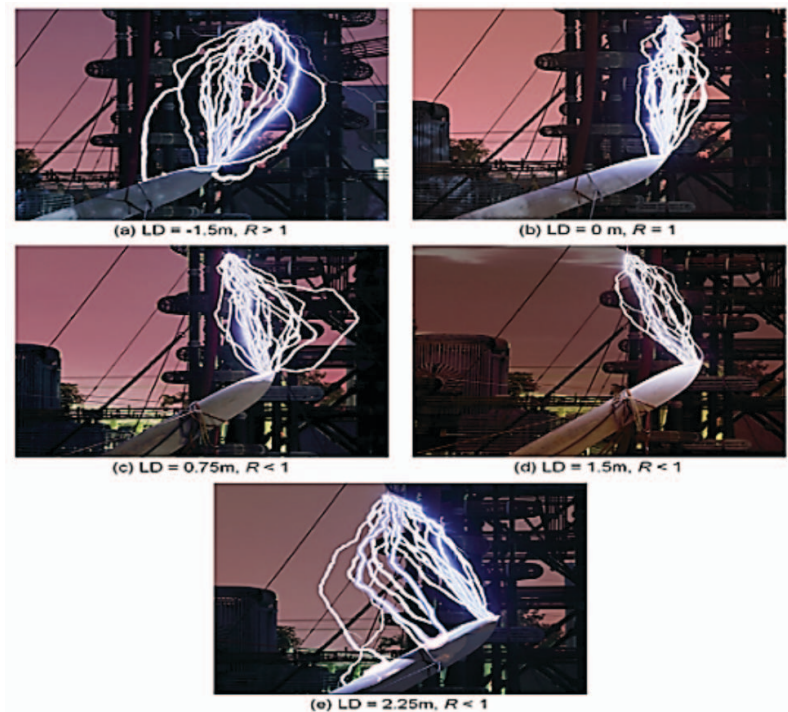

Fig. 7. (a) The paths of total 20 times discharges for $\mathrm{LD}=-1.5 \mathrm{~m}, \mathrm{R}>1$. (b) The paths of total 20 times discharges for $\mathrm{LD}=0 \mathrm{~m}, \mathrm{R}=1$. (c) The paths of total 20 times discharges for $L D=0.75 \mathrm{~m}, \mathrm{R}<1$. (d) The paths of total 17 times discharges for $\mathrm{LD}=1.5 \mathrm{~m}, \mathrm{R}<1$. (e) The paths of total 20 times discharges for $\mathrm{LD}=2.25 \mathrm{~m}, \mathrm{R}<1$.

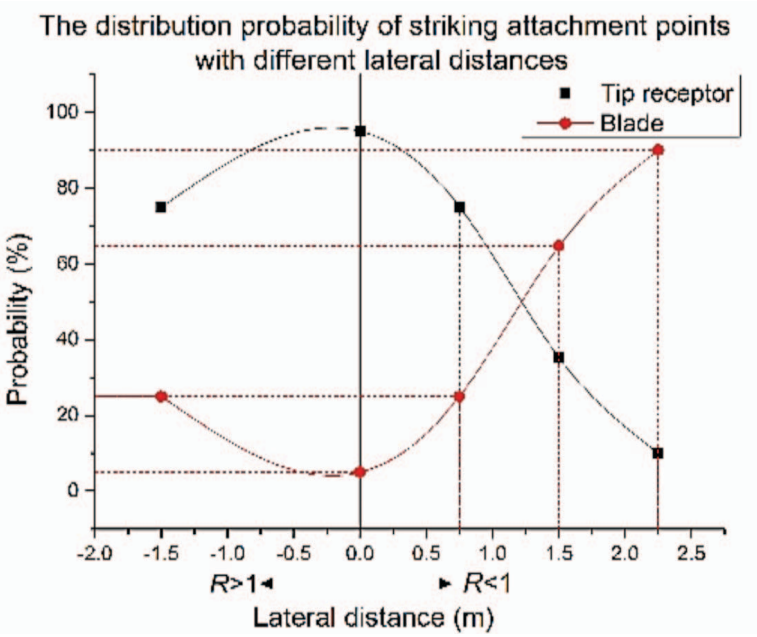

Fig. 8. The distribution probability of striking attachment point with different lateral distance

\section{Three patterns of receptor interception failure}

To figure out how receptor fails to intercept lightning strikes is the first step to improve the design of LPS. The experiments with positive impulses under orientation of $30^{\circ}$ with horizontal $(\mathrm{LD}=2.25 \mathrm{~m})$ are conducted as results are given in Table III. In the experiments, three typical interception failure patterns were observed for positive standard switching impulses, as follows:

- Creeping discharge from receptor along the leading/trailing edge (Figure 9(a))

- Discharge hitting on blade leading/trailing edge (Figure 9(b))

- Discharge hitting on blade surface directly (Figure 9(c))

In the experiments, more than half of the cases of receptor interception failure were creeping discharges from receptor along the leading/trailing edge. In general, about $4 \mu \mathrm{s}$ ( 1 frame) before return stroke, creeping discharge develops on the leading/trailing edge from the boundary of receptor and blade to downward leader, as shown in Figure 9(a). Then upward leader incepts from the discharge channel and connects to downward leader.

Experimental results show that, the leading/trailing edge of blade is the second vulnerable position of discharges, as shown in Figure 9(b). The discharges can hit on blade leading/trailing edge very close to the tip receptor $(44 \mathrm{~cm}$ from the blade tip). Although the energy of the impulse is not so large, it really causes damage to the wind turbine blade. 
TABLE III

DISCHARGE MANNER FOR ORIENTATION OF $30^{\circ}$ WITH HORIZONTAL

\begin{tabular}{|c|c|c|c|c|c|c|c|c|c|c|c|c|c|c|c|}
\hline \multirow{4}{*}{$\begin{array}{c}\begin{array}{c}\text { Lateral } \\
\text { distance } \\
(\mathrm{m})\end{array} \\
1.5\end{array}$} & \multirow{4}{*}{$\begin{array}{c}\mathrm{R}_{\text {tip-bottom }} \\
\quad<1\end{array}$} & \multirow{4}{*}{$\begin{array}{c}\begin{array}{c}\text { Average } \\
\text { breakdown } \\
\text { voltage } \\
(\mathrm{kV})\end{array} \\
1481.49\end{array}$} & \multicolumn{12}{|c|}{ Attachment point } & \multirow{4}{*}{$\begin{array}{l}\text { total } \\
20\end{array}$} \\
\hline & & & \multicolumn{6}{|c|}{ Tip receptor } & \multicolumn{6}{|c|}{ Blade surface } & \\
\hline & & & \multicolumn{2}{|c|}{ Receptor tip } & \multicolumn{2}{|c|}{$\begin{array}{c}\text { Receptor } \\
\text { side }\end{array}$} & \multicolumn{2}{|c|}{ subtotal } & \multicolumn{2}{|c|}{$\begin{array}{l}\text { Close to tip } \\
\text { receptor }\end{array}$} & \multicolumn{2}{|c|}{$\begin{array}{l}\text { far from tip } \\
\text { receptor }\end{array}$} & \multicolumn{2}{|c|}{ subtotal } & \\
\hline & & & 4 & $20 \%$ & 11 & $55 \%$ & 15 & $75 \%$ & 2 & $10 \%$ & 3 & $15 \%$ & 5 & $25 \%$ & \\
\hline 0 & $=1$ & 1423.95 & 5 & $25 \%$ & 14 & $70 \%$ & 19 & $95 \%$ & 1 & $5 \%$ & 0 & $0 \%$ & 1 & $5 \%$ & 20 \\
\hline 1.5 & $>1$ & 1268.06 & 1 & $6 \%$ & 5 & $29 \%$ & 6 & $35 \%$ & 11 & $65 \%$ & 0 & $0 \%$ & 11 & $65 \%$ & 17 \\
\hline 2.25 & $>1$ & 1466.10 & 0 & $0 \%$ & 2 & $10 \%$ & 2 & $10 \%$ & 10 & $50 \%$ & 8 & $40 \%$ & 18 & $90 \%$ & 20 \\
\hline
\end{tabular}

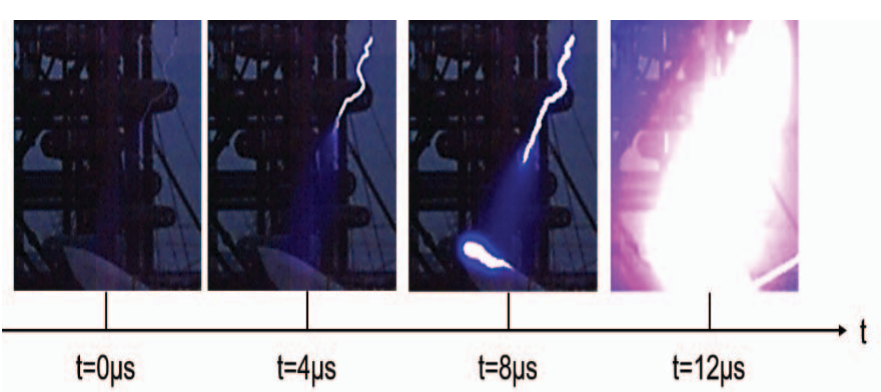

(a) Creeping discharge from receptor along the leading/trailing edge
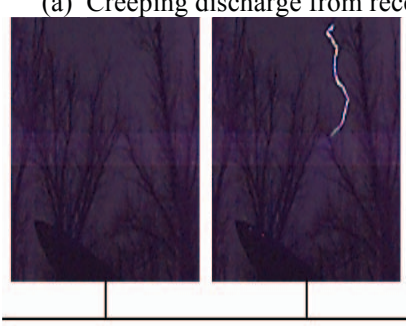

$\mathrm{t}=0 \mu \mathrm{s}$

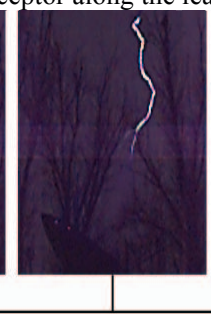

$t=8 \mu \mathrm{s}$

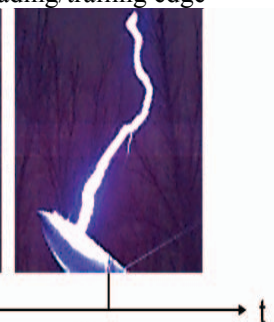

$t=12 \mu s$

(b) Discharge hitting on blade leading/trailing edge

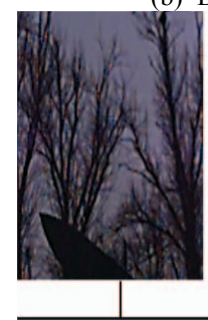

$\mathrm{t}=0$ us

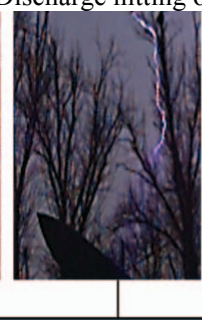

$t=4 \mu s$

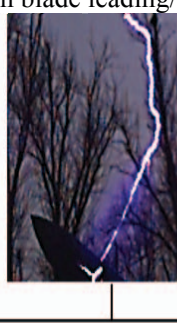

$t=8 \mu s$

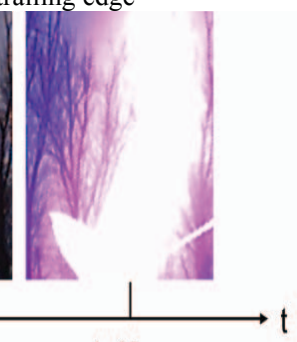

$t=12 \mu s$

(c) Discharge hitting on blade surface directly

Fig. 9. Three patterns of receptor interception failure. Pictures are taken by high speed camera.

In third type of interception failure, the discharge can bypass the edge and hit on the blade surface directly. As shown in Figure 9(c), upward leaders incept both from edge and surface of blade, and discharge finally hits on the surface. Although the upward leader that incepts from leading edge connected the downward leader, the discharge continues to go downward to the upward leader which incepts from blade surface, and finally hit on blade surface.

\section{DISCUSSION}

The experimental results show strong polarity effect, as positive lightning strikes are difficult to be intercepted by receptor. It can be regarded that the results won't be influenced by the nearby objects and the surroundings won't affect the electric field in the long air gap. The space charges caused by corona disturb the electric field near the receptor, which influence the inception of upward leader.

With lateral distance increasing, the distribution of striking attachment points shows a tendency that striking attachment point moves away from tip receptor, as shown in Figure 10. When lateral distance is $0 \mathrm{~m}$, most discharges hit on receptor tip and side, then with the increasing of LD, more discharges hit on the blade surface near the boundary of receptor and blade body and cause creeping discharges instead of hit on the receptor. When lateral distance is large enough, the receptor fails to attract most downward leaders and discharges hit on the surface of blade body.

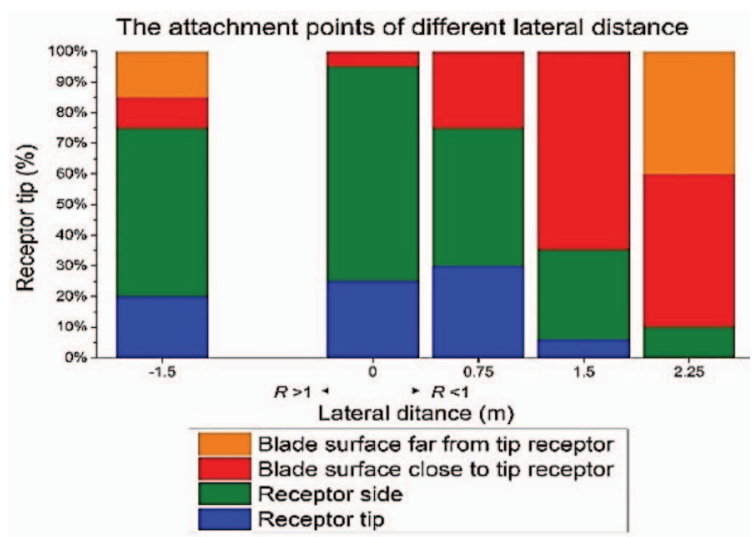

Fig. 10. The striking attachment points of different lateral distances.

In this paper, the experiments were conducted with standard switching impulses and it has be found that the tip receptor performs very well under negative impulses. However, the tip receptor fails to intercept discharge under positive impulses. If lightning impulse is more severe than switching impulses then polarity effect will be more pronounced with lightning impulses, and the influence of lateral distance will be more obvious, which will further prove the conclusion in this paper. 


\section{CONCLUSIONS AND RECOMMENDATIONS}

Experiments of lightning attachment were conducted to study the inception performance of WT blade with LPS under different blade orientations and lateral distance. The conclusion can be summarized as follows.

1. The lateral distance between lightning downward leader and wind turbine blade is one of the key factors of receptor interception efficiency. The protection area of receptor shows obvious asymmetry when lateral distance is different, and discharges can be intercepted more efficiently when $\mathrm{R}>1$ than $\mathrm{R}<1$.

2. There are three patterns of receptor interception failure found in experiments: creeping discharge from receptor along the leading/trailing edge, discharge hitting on blade leading/trailing edge and discharge hitting on blade surface directly.

3. WT blade orientation also effects the performance of LPS. Interception efficiency of LPS decreases when WT blade moves from vertical to horizontal position.

4. Although the occurrence of positive lightning strikes is one ninth of negative one, positive lightning strikes have much higher peak current and are more scattering than negative ones, which is possible to lead to interception failure of receptor. So, more attention should be paid while designing and testing of LPS of WT blade for positive lightning strikes.

\section{FUTURE WORK}

Experimental study of electric field distribution inside and outside of the wind turbine blade, because it will help to determine the upward leader initiation, then lightning protection system of the wind turbine blade can be improved.

\section{ACKNOWLEDGMENT}

This work was supported by National Natural Science Foundation of China (NNSFC) (51420105011) and the Fundamental Research Funds for the Central Universities (2016XS06). The authors would like to particularly thank to the staff of Shahe testing yard of North China Electric Power Research Institute (NCEPRI) for their consistent support throughout the experiment procedure.

\section{REFERENCES}

[1] Kusiak and W. Li, "The prediction and diagnosis of wind turbine faults," Renewable Energy, Vol. 36, No. I, pp. 1623,2011.

[2] R. B. Rodrigues, V. M. F. Mendes and J. P. S. Catalilo, "Protection of wind energy systems against the indirect effects of lightning," Renewable Energy, Vol. 36, No. II, pp. 28882896, 2011.

[3] S. F. Madsen, J. Holboll, M. Henriksen, K. Bertelsen and H. V. Erichsen, "New test method for evaluating the lightning protection system on wind turbine blades," Proceedngs of the 28th International Conference of Lightning Protection,Kanazawa (Japan),2006.

[4] T. Naka, N. 1. Vasa, S. Yokoyama,A. Wada, A. Asakawa,H. Honda,K. Tsutsumi and S. Arinaga, "Study on lightning protection methods for wind turbine blades," IEEJ Trans. PE,Vol. 125,No. 10, pp. 1-8,2005.

[5] S. F. Madsen and H.V. Erichsen, "Numerical model to determine lightning attachment point distributions on wind turbines according to the revised IEC 61400-24," Proc. of the International Conference on Lightning and Static Electricity (ICOLSE), Pittsfield, Massachusetts, USA, 15-17 September 2009.

[6] H. Braam, "Lightning damage of owecs, Part 1: Parameters relevant for cost modelling," ECN-C-02-053, Jun. 2002.

[7] R. Beckers. Lightning Protection, 2016. [Online]. Available: http://www.solacity.com/lightning-protection/

[8] Ishii M, Saito M, Natsuno D, et al, "Lightning incidence on wind turbines in winter," 2014 32rd International Conference on Lightning Protection (ICLP), Shanghai, 2014, pp. 17341738 .

[9] NJ. Vasa, T. Naka, S. Yokoyama, A. Wada, A. Asakawa, S. Arinaga, "Experimental study on lightning attachment manner considering various types of lightning protection measures on wind turbine blades," Proceedings of the 28th International Conference on Lightning Protection (ICLP), Kanazawa, Japan, 2006, pp. 1483-1487.

[10] S. Arinaga, K. Tsutsumi, et al, "Experimental Study on Lightning Protection Methods for Wind Turbine Blades," 2006 28rd International Conference on Lightning Protection (ICLP), Kanazawa, Japan, 2006, pp.1493-1496.

[11] T. Shindo, A. Asakawa, M. Miki, "A study of lightning striking characteristics to wind turbines," 29th International Conference on Lightning Protection (ICLP), Uppsala, 2008, pp. 9c-4-1 - 9c-4-9.

[12] Montanyá J, March V, Hermoso B, et al, "High-speed videos of laboratory leaders emerging from wind turbine blade tips," Lightning Protection (ICLP), 2010 30th International Conference on. IEEE, 2010, pp. 1-5.

[13] Yokoyama S, "Lightning protection of wind turbine blades," Electric Power Systems Research, 2013, 94: 3-9.

[14] A.M. Abd-Elhady, N. A. Sabiha, M. A. Izzularab, "Experimental evaluation of air-termination systems for wind turbine blades." Electric Power Systems Research 107 (2014): 133-143 